\title{
The Relationship Of Development Status Of Investee Countries And Investor Perceptions Of Foreign Earnings
}

\author{
Chen-Lung Chin, National Chengchi University, Taiwan \\ Yu-Ju Chen, National Changhua University of Education, Taiwan \\ Gary Kleinman, Montclair State University, USA \\ Picheng Lee, Pace University, USA
}

\begin{abstract}
This study investigates the impact of corporate internationalization and the development status of investee countries on the foreign earnings response coefficient (FERC), which is a measure of the value-relevance of foreign earnings. To improve competitiveness, firms worldwide have expanded aggressively into foreign markets, thereby increasing their exposure to external risks and uncertainties on the one hand, and sources of growth and reward on the other. Using a Taiwanese sample, we found that greater corporate internationalization via investments in developed countries was positively related to the foreign ERC. We expected, and found, that companies can enhance the positive effects of internationalization by investing in countries that are relatively better developed than in countries that are less well developed. The public policy implications of these findings are discussed.
\end{abstract}

Keywords: Internationalization; Economic Development; Value Relevance of Foreign Earnings

\section{INTRODUCTION}

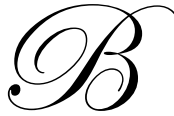

usinesses always have the ability to choose whether to devote their investment resources to investing domestically only, or in other countries, or a combination of the two. Businesses that choose to invest outside their national borders further face the choice of investing in more versus lesser developed countries. It is commonly understood that businesses pursue overseas (external) diversification as part of a strategy to take advantage of profit potentials overseas. The international diversification may also result in a more efficient allocation of capital and greater economic growth. The public policy implications of this diversification, however, are less clear cut since diversification may result in capital being allocated to international locales where the investment may be subject to great uncertainty. For example, investments in emerging markets, or lesser developed countries, may cause investors to believe that repatriation of investment profits and investment capital itself may be uncertain. In addition, investing in lesser developed countries may expose the investing firm to political and economic instability that may not exist in more developed economies, economies that are almost axiomatically more integrated with established international economic, financial and investment practices and mores. Further, investing businesses are more likely to be able to acquire greater amounts and quality of information on more (as opposed to lesser) developed countries. Accordingly, investors may be more likely to perceive foreign investments in more developed countries in a better light and therefore see greater value in earnings derived from them. This may lead to a higher value relevance of earnings.

Prior research has shown that successful internationalization will lead to higher earnings growth rates and greater earnings persistence (e.g., Duru and Reeb, 2002). While prior accounting studies on internationalization focus primarily on differences in the value relevance of foreign versus domestic earnings (e.g., Bodnar, Hwang and Weintrop, 2003; Bodnar and Weintrop, 1997), little work to date examines whether the market's perception of the value relevance of foreign earnings varies among firms that differentially invest in more (versus lesser) developed countries. Given the widely bruited importance of globalization and cross-national cooperation and investment, this 
is an important deficit in current research. We seek to address this lack here. Specifically, we investigate the association between a company's decision to invest in countries considered more developed (as opposed to less developed) and the market's perception of value relevance of the firm's foreign earnings (see, for example, Makino, Lau and Yeh, 2002).

This paper offers several contributions. First, our study contributes to research on the association between internationalization and the value relevance of earnings. Unlike prior studies (i.e., Bodnar and Weintrop, 1997; Bodnar et al, 2003), which focus on countries of Anglo-Saxon cultural derivation, ${ }^{1}$ we use Taiwan's data and find that the market's perception of the value relevance of foreign earnings varies among firms with different international diversification profiles, specifically investments in more (versus less) developed countries, using Makino et al.'s (2002) classification of the same. This is important in that internationalization may threaten the firm with the possibility that domestic influences in foreign markets will impact the corporation's ability to assert control over its own investments.

Further, this study contributes to literature on effectiveness of regulation in providing information valuable to investors. Regulation issues exist both within and across national boundaries, consistent with increasing levels of globalization of economic activity and investments. Our study demonstrates that segment disclosure has great value to investors in that the results help the investors evaluate the impact of foreign investments in more (versus lesser) developed countries and the attendant uncertainties on the firm's expected future performance.

Our empirical findings suggest that the market's perception of the value relevance of foreign earnings does not significantly differ from that of domestic earnings. We do find, however, that the impact of foreign earnings on stock returns is significantly enhanced as a firm's international diversification profiles (measured by country scope and the number of foreign investees) increase. Furthermore, greater investment in more (as opposed to lesser) developed countries enhances the positive effects of internationalization on the value relevance of foreign earnings.

\section{INSTITUTIONAL BACKGROUND AND RELATED LITERATURE}

\section{Internationalization and Foreign Earnings}

The importance of understanding the determinants of the value relevance of foreign earnings is evident from the increasing part that international operations play in the lives of many firms. Specifically, as foreign involvements grow, the potential impact of these foreign operations on total firm earnings grows apace. Bodnar et al. (2003) argue that foreign involvement may have both positive and negative effects on the value relevance of earnings, both domestic and foreign, as will be described in detail later.

Duru and Reeb (2002) note that the impact of international diversification may be to increase the complexity of forecasting the firm's earnings due to many factors. Status of the investee's country's development may add to forecasting complexity problems. Expressed in terms of the investing public, this greater uncertainty may lead to a higher risk premium being built into the stock price. Jiraporn, Kim and Mather (2005) note that diversified firms may suffer a value discount due to agency costs associated with the diversification. We suggest that the development status of an investee country may increase these agency costs, with agency costs higher for investments made in countries that are less developed due to the relative lack of sophistication of their legal, regulatory and economic infrastructures. This problem impacts foreign operations on the value relevance of the firm's foreign earnings. ${ }^{2}$

1 Bodnar et al. (2003) studied the impact of non-domestic earnings on the earnings response coefficient of Australia, the United Kingdom and Canada. Bodnar et al. (2003) extended the research of Bodnar and Weintrop (1997). The latter examined the relative impact of foreign and domestic earnings on US stock prices.

2 See Duru and Reeb (2002) for a review of the impact of foreign operations on firm earnings and the ability of analysts to forecast the followed firm's earnings. 


\section{Emerging Market in Taiwan}

Two factors motivate us to use Taiwanese firms' data in this study. First, internationalization becomes an important strategy for a firm's growth in emerging countries. Taiwan is characterized by heavy reliance on exports, smaller stock markets, higher ownership concentrations, weaker investor protections, and lower disclosure requirements. Therefore, the effect of internationalization on the value relevance of a Taiwanese firm's foreign earnings should be more pronounced. Until relatively recently, it was also a lesser developed country. Therefore its experience with overseas investments may be less sophisticated than investors from countries that have been developed for a longer time. Finally, while not many countries require segment disclosures, our findings suggest the importance of these disclosures.

\section{HYPOTHESIS}

Internationalization via investment in other countries may produce contradictory effects on the value relevance of corporate earnings. These effects may differ based on the developmental status of the different investee countries. In this paper, we will investigate such effects.

\section{Positive Effects}

Previous studies suggested that companies may engage in internationalization because they possess such advantages as ownership, location, and internalization (Dunning, 1998). Thus, successful internationalization requires not only substantial resources, but also accumulated experiences and capabilities, including multi-point operations and foreign investment networks. Such intangible assets or advantages are difficult for competitors to imitate. In the early stages, internationalization costs may exceed the benefits. Thus, corporate international diversification may negatively affect performance. Over time, however, costs of internationalization gradually decrease until benefits exceed the costs. Diversification's benefits to the firm include the knowledge and experience gained from foreign markets, as well as the increased stability given to overall corporate operations by the geographic diversification of the firm's activities, spreading those activities to markets whose economic performance is loosely correlated with that of the firm's home market. Duru and Reeb (2002) also note the firm's ability to shift costs between their foreign branches in order to minimize their taxes. Duru and Reeb (2002) further noted the greater persistence of overseas profits. Hence, there will be positive effects on such performance indicators as profits and growth rates (Lu and Beamish, 2001; Lu and Beamish, 2004).

International diversification may be one of the most important strategies for pursuing corporate growth and profits and improved market position. Many studies point out that cross-border investments are able to generate many benefits and enhance corporate performance (Hitt et al., 1997; Tallman and Li, 1996). Thus, greater internationalization indicates the possibility of both a higher growth rate and earnings continuity, thereby increasing value relevance of corporate earnings (see Collins and Kothari, 1989; Duru and Reeb, 2002). We suggest, therefore, that internationalization will increase the value relevance of corporate earnings. Investing in a more (as opposed to lesser) developed country may add a greater perceived likelihood of the investment being a success due to the greater stability of the host government and existence of established economic and industrial infrastructure, as well as norms promotive of external development resources. Thus investing in a more (as opposed to lesser) developed country may result in higher perceived stability and continuity of the related earnings flow and, accordingly, a higher value relevance of earnings.

\section{Negative Effects}

Contrary effects may exist too. For example, internationalization-related investments are similar to the creation of intangible assets in that the surplus value to be garnered in the future via the overseas expansion cannot be captured in the financial reports directly, nor can the costs of establishing a presence overseas be capitalized (see Lev and Zarowin, 1999; Chin et al., 2006). Also, high levels of uncertainty surround the realization of benefits from the venture. Further, international operations encounter more complex environments than do domestic ones, which results from operating in environments that may differ substantially from the firm's home environment. The dimensions of difference include cultural differences, customer tastes, and different institutional and competitive 
conditions (e.g., Gomez-Mejia and Palich, 1997). Level of development may also have an impact. Thus, companies are confronted with higher operational and financial risks. Accordingly, it becomes more difficult to predict future earnings based on accounting information (e.g., Collins and Kothari, 1989).

Internationalization involves cross-border operations. Investments in multiple countries makes financial reports complex since there may be related parties' transactions with companies or affiliates abroad or side deals between management and suppliers or customers that are less visible to the board of directors in the home country. Even when approved by the board of directors, the transactions may only be in the interest of management or of the firm's controlling owner(s) (e.g. Faccio, Lang and Young, 2001; Jiraporn, Kim and Mather, 2005.) This diminishes the transparency of accounting information and thereby diminishes the minority investors' ability to monitor controlling owner and manager behaviors (Maines and McDaniel, 2000). If so, current earnings will have only spurious connections with the firm's future operational performance, resulting in a reduced value relevance of earnings. An additional problem is that the corporate board will find it difficult to adequately supervise and control management. Further, auditors may find their own effectiveness diminished as the need to coordinate efforts across multiple cultures and locations grows. Whether these problems are more acute in lesser (as opposed to more) developed investee countries due to the latter's relatively more limited experience dealing with the financial markets and cross-border capital flows is an open question. Also, investments in more developed countries may result in the acquisition of higher priced assets - since they are more developed, thereby reducing the assets earning potential.

Since the impact of corporate internationalization on the value relevance of earnings may be either positive or negative, it merits further investigation. The value relevance of earnings, however, is a complex concept. Lipe (1986), for example, proposed that earnings components have different levels of value relevance (e.g., Bodnar et al., 2003). Corporate internationalization, of course, should mostly influence foreign earnings and the value relevance of foreign earnings. Due to the competing theoretical arguments, we test the following hypothesis:

H1: The degree of corporate internationalization to developed (as opposed to lesser) developed countries is associated with the magnitude of the value relevance of foreign earnings.

\section{RESEARCH DESIGN}

\section{Sample}

Our sample includes Taiwanese publicly-listed firms. The sample years ranged from 2002 to 2007. Following Bodnar and Weintrop (1997), ${ }^{3}$ foreign operations are defined as operations that are located outside of the registrant's home country. We also define the firm's export income to be a constituent of the firm's domestic income. To enhance the information transparency of listed companies in Taiwan, the Taiwan Stock Exchange Corporation Rules Governing Information Reporting by Listed Companies (therefore TSECRG) ${ }^{4}$ require publiclylisted firms to disclose the following information about their overseas investments:

1. the number of foreign investees

2. the assets of foreign investees

3. the number of countries where the foreign investees are

4. the profit or loss resulting from these foreign investee investments

This enabled us to break down total corporate earnings into their domestic and foreign earnings components. We used the consolidated financial statements as a source of information, rather than that reported by unconsolidated foreign subsidiaries themselves, because the former is more transparent.

3 U. S. SEC regulation \$210.4-08(h), entitled General Notes to Financial Statements-Income Tax Expense, requires firms to disclose information about their domestic and foreign operational performance in either their income statements or footnotes. The regulation defines foreign operations as operations located outside of the SEC registrant's home country. Export-derived income is defined to constitute part of the firm's domestic income segment (see Bodnar and Weintrop, 1997).

4 These rules were issued based on Article 2 of the Securities Listing Contract and Article 2 of the Beneficiary Certificate Listing Contract. The Securities Listing Contract was issued based on Article 140 of Taiwan Securities and Exchange Act. See http://eng.selaw.com.tw/FLAWDAT0202.asp (as of 4/21/2008. 
Our sample firm-years had to meet the following requirements:

1. The TEJ database had to contain the required financial data for all necessary variables and

2. None of the sample firms could be in any regulated industry (e.g., finance, banking and utilities).

These requirements resulted in a total of 909 firms, with a final sample of 3,653 firm-years. Firms in the electronics industry comprise approximately $58.25 \%$ of the sample. Over the five-year panel of data, the number of sample observations increases year by year, perhaps because of an increase in the number of publicly-listed companies.

\section{Models}

We use equation (1) to estimate ERC.

$$
R_{i t}=\beta_{O}+\beta_{1} \Delta E_{i t}+\varepsilon_{i t}
$$

$R_{i}$ refers to raw stock returns. ${ }^{5}$ Following Bodnar et al. (2003), $\Delta E_{i t}$ is the change in earnings per share, before the impact of extraordinary items is taken into account, and is equal to $E P S_{i t}-E P S_{i t-1}$, scaled by the price of the firm's share at the beginning of year. Earnings is defined as reported earnings before extraordinary items of firm $\mathrm{i}$ in fiscal year t. ERC is equal to $\beta_{1}$ in equation (1). Following Bodnar et al. (2003), we divided the change in earnings $(\Delta E)$ into two groups - the change in domestic earnings $(\triangle D E)$ and the change in foreign earnings $(\triangle F E)$.

$$
R_{i t}=\beta_{O}+\beta_{1} \Delta D E_{i t}+\beta_{2} \Delta F E_{i t}+\varepsilon_{i t}
$$

$\beta_{1}$ refers to the domestic value relevance of earnings and $\beta_{2}$ to the value relevance of foreign earnings. Lower coefficient values indicate a lower value relevance of earnings as judged by investors (Lev and Zarowin, 1999). We expect that both foreign and domestic earnings are related to stock returns. In order to test the hypotheses, we present the following equation:

$$
\begin{aligned}
R_{i t}= & \alpha_{0}+\alpha_{1} \Delta D E_{i t}+\alpha_{2} \Delta F E_{i t}+\alpha_{3} \Delta F E_{i t} \times I N T_{i t}+\alpha_{4} \Delta F E_{i t} \times D E V E_{i t} \\
& +\alpha_{5} I N T_{i t}+\alpha_{7} S I Z E_{i t}+\sum Y E A R+\sum I N D+\varepsilon_{i t}
\end{aligned}
$$

We use equation 3 to test our hypothesis. We predict that investment in developed countries, as opposed to countries not classified as developed, will lead to greater returns. That is, we expect that investing in developed countries (DEVE, which equals 1 for developed countries and 0 for other countries) - defined based on Makino, Lau and Yeh (2002) - will lead to greater value relevance of earnings. In contrast, investing in less developed countries $(\mathrm{DEVE}=0)$ will lead to lower value relevance of earnings. Other variables are defined as follows.

\section{Internationalization (INT)}

Prior studies have recommended a variety of measures to gauge international diversification. We define internationalization as increasing as the following increase:

1. FC (country scope): the number of foreign countries in which firms have an investment

2. $\quad$ FI (foreign investees): the number of foreign investees

5 Collins and Kathori (1989) found that the results of cumulative abnormal returns are similar to those of general raw returns. Also, Beaver, Lambert, and Ryan (1987) report that the earnings/returns relation is essentially the same whether one uses raw return or market model prediction errors. Thus, we use the general returns to be the dependent variable. 


\section{Control Variables}

We include corporate size $\left(\mathrm{SIZE}_{\mathrm{i}}\right)$, industry $\left(\mathrm{IND}_{\mathrm{i}}\right)$, and yearly effect $\left(\mathrm{YEAR}_{\mathrm{t}}\right)$ as control variables. $\mathrm{SIZE}_{\mathrm{it}}$ was measured by the natural logarithm of total assets. YEAR includes a set of dummy variables representing the fiscal year and IND includes a set of dummy variables representing the industry.

\section{EMPIRICAL RESULTS}

\section{Descriptive Statistics}

The sample's descriptive statistics are as follows: The average stock return equaled $17.58 \%$, average unexpected earnings equaled 0.0361 , and average $\triangle D E$ is equal to 0.0342 . Average $\triangle F E$ is equal to 0.0024 . On average, firms have investments in 3.26 foreign countries (FC). Also, the average number of foreign investees (FI) is 6.41. The averages of DEVE_FC and DEVE_FI are 0.69 and 0.645 , respectively. The logarithm of total assets (SIZE) is equal to 9.6038 (approximately US $\$ 375$ million).

In order to examine the multicollinearity between the variables, we used the procedures proposed by Kennedy (1992) to calculate the VIF (variance inflation factors) values. The results suggest no multicollinearity problem. All VIF values were less than 10.

\section{Analysis of OLS Regression}

The results of the OLS regression are presented in Table 1 . Since problems of heteroscedasticity generally occur in regression analyses, we substitute the White-adjusted $t$-statistic (White, 1980) for $t$-statistics (hereafter), and make related inferences accordingly.

In Table 1, Model 1, we split earnings into the domestic and overseas components, allowing us to observe each one's relationship with stock returns as well as evaluate the relative influences of each on stock returns. Model 1 shows that both of them are positive with the value relevance of foreign earnings being lower than that of domestic earnings ( 0.886 versus 0.979$)$. The difference in these two coefficients is statistically significant at the five percent level $(t$-value $=2.288)$. The results here indicate that investors respond less strongly to overseas markets-derived earnings than from domestic earnings.

We measured the degree of internationalization by the number of foreign countries in which firms have investments (FC) and the number of foreign investees (FI), separately. Models 1 and 2 show the impacts on stock returns of the number of foreign countries in which firms have investments (FC) and the number of foreign investees (FI), respectively. The results of Models 1 and 2 in Table 1 show that the value relevance of $\triangle D E$ is greater than that of $\triangle F E$ in Model 1, but not Model 2. However, the coefficient of the interaction term of $\triangle F E$ and the foreign assets ratio $(\mathrm{FC})$ was not significant in Model 1, nor was the coefficient of the interaction term of $\triangle F E$ and the foreign investee ratio (FI) significant in Model 2. The results reveal that just increasing the number of foreign countries that the sample firms invested in did not, in itself, increase the value relevance of the corporation's foreign earnings.

Table 1 also shows that all coefficients of $\triangle F E *$ DEVE_FC and $\triangle F E *$ DEVE_FI are positive and highly significant at the $1 \%$ level. This result suggests that investors are more likely to attribute higher value relevance to foreign earnings when they were generated in developed (as opposed to lesser) developed countries.

For both regressions, the coefficients of SIZE are significant and positive at the one percent level. The adjusted $\mathrm{R}^{2} \mathrm{~s}$ of the regressions shown in Table 1 range from $20.5 \%$ to $20.6 \%$ with all the VIF values being below 6 . The results suggest that multicollinearity is not severe (Kennedy, 1992). ${ }^{6}$

6 In order to confirm that the results do not stem from the influence of outliers, we follow the procedures as suggested by Belsley, Kuh, and Welsch (1980) to eliminate outliers. The results of the regression without the outliers remain consistent with the results for the total sample. Hence, the results of the study are robust (We do not report these results in the tables.) 
In short, corporate internationalization may have positive effects on the value relevance of foreign earnings, with companies able to enhance that effect by investing in more (as opposed to) lesser developed countries. Doing so may reduce the risk to the investing company itself.

Table 1: Regression Analysis between Internationalization and Value Relevance of Foreign Earnings

\begin{tabular}{|c|c|c|c|}
\hline Independent Variables & Sign & Model 1 & Model 2 \\
\hline Constant & & $\begin{array}{c}-0.424 \\
(0.005)^{* * *}\end{array}$ & $\begin{array}{c}-0.408 \\
(0.000)^{* * *}\end{array}$ \\
\hline$\Delta \mathrm{DE}$ & + & $\begin{array}{c}0.979 \\
(0.000)^{* * *}\end{array}$ & $\begin{array}{c}0.990 \\
(0.000)^{* * * *}\end{array}$ \\
\hline$\Delta \mathrm{FE}$ & + & $\begin{array}{c}0.886 \\
(0.000)^{* * *}\end{array}$ & $\begin{array}{c}1.138 \\
(0.000)^{* * * *}\end{array}$ \\
\hline$\Delta \mathrm{FE} * \mathrm{FC}$ & $?$ & $\begin{array}{c}0.042 \\
(0.377) \\
\end{array}$ & \\
\hline$\Delta \mathrm{FE} * \mathrm{FI}$ & $?$ & & $\begin{array}{c}-0.022 \\
(0.257) \\
\end{array}$ \\
\hline$\Delta \mathrm{FE} * \mathrm{DEVE} \_\mathrm{FC}$ & & $\begin{array}{c}0.053 \\
(0.001)^{* * *}\end{array}$ & \\
\hline$\Delta \mathrm{FE} * \mathrm{DEVE} \_\mathrm{FI}$ & & & $\begin{array}{c}0.022 \\
(0.000)^{* * * *}\end{array}$ \\
\hline $\mathrm{FC}$ & $?$ & $\begin{array}{c}-0.013 \\
(0.012)^{* *}\end{array}$ & \\
\hline FI & $?$ & & $\begin{array}{c}-0.001 \\
(0.527)\end{array}$ \\
\hline SIZE & + & $\begin{array}{c}0.053 \\
(0.001)^{* * *}\end{array}$ & $\begin{array}{c}0.047 \\
(0.006)^{* * * *}\end{array}$ \\
\hline IND & & YES & YES \\
\hline YEAR & & YES & YES \\
\hline $\mathrm{F}$ & & 36.109 & 35.745 \\
\hline Adjusted $\mathrm{R}^{2}$ & & $20.6 \%$ & $20.5 \%$ \\
\hline $\mathrm{N}$ & & 3648 & 3648 \\
\hline
\end{tabular}

The number in parentheses is p value. *,**, and *** denotes significance at the $10 \% ; 5 \%, 1 \%$, respectively.

R: stock returns

DE: domestic earnings

FE: foreign earnings

$\Delta \mathrm{E}$ : the change in earnings

$\triangle \mathrm{DE}$ : the change in domestic earnings

$\triangle \mathrm{FE}$ : the change in foreign earnings

FC: the number of foreign countries in which firms have investments

FI: the number of foreign investees

DEVE: 1 for developed countries, and 0 for other countries

SIZE: the natural logarithm of total assets

IND: dummy variables representing the industry.

YEAR: dummy variables representing the fiscal year;

Notes: To preserve space, the statistical results of the year and industry dummy variables are omitted from the tables.

\section{Sensitivity Analyses}

\section{Averaging Individual Firm Observations}

Our sample period ranges from 2002 to 2007. The empirical results may generate spurious results because of our use of panel data. In our analyses, sample companies may generate six observations with each six having similar sample characteristics. To further investigate the robustness of our empirical results, we averaged all the observations available for a given firm and then used the average of the observations in the regressions (Greene, 2000). The final simplified sample includes 909 observations. Thus, the results are not attributable to the frequencies with which a company appears in the analyses. The empirical results are robust. 


\section{Earnings Level As Another Explanatory Variable}

We included earnings level as an additional explanatory variable since, as Bodnar et al. (2003) show, it may importantly impact annual returns. Bodnar et al. (2003) note that the earnings levels incorporate something they dubbed 'transitory' components of earnings and said that they are important in predicting annual firm returns. The impact of transitory earnings components is not captured by earnings changes in themselves. Accordingly, we also include earnings level as an additional explanatory variable in our returns regressions. Earnings level $\left(E P S_{i t}\right)$ is calculated as earnings per share scaled by the firm's share price at the beginning of the year. The earnings level can be divided into two components - domestic earnings (DE) and foreign earnings (FE). The empirical results reveal that our primary conclusions remain unchanged. Thus, our inferences are likely not due to the omitted variables.

\section{CONCLUSION}

This paper investigates the effects of internationalization on the value relevance of foreign earnings and enriches our understanding of the factors that influence these coefficients. In order to build greater competitiveness, Taiwan's companies have expanded aggressively into foreign markets. This paper demonstrates the impact of those investments on investor perception of the value of earnings generated by the sample firms. It demonstrates the greater confidence that investors seem to have when Taiwanese firms invest in more (as opposed to) less developed countries.

This paper includes 3,653 Taiwanese publicly-listed, non-financial, firm-year sample observations for the period 2002-07. Specifically, we investigate the association between a company's decision to invest in countries considered more developed (as opposed to less) and the market's perception of the value relevance of the firm's foreign earnings, derived from countries Makino et al. (2002) characterize as developed, to the total number of investee countries, and the ratio of foreign investees in developed countries to the total number of foreign investees to proxy for corporate internationalization. Our empirical findings suggest that an aggressive internationalization strategy in developed countries has a positive effect on the value relevance of foreign earnings because foreign investments bring about growth and profits. The risks include exposing corporate overseas investments to expropriation in the investee countries. This study demonstrates the differential effects of national development status on investor reaction to these risks.

Investments in multiple countries make financial reports more complex since related parties' transactions in multiple countries will undermine the transparency of accounting information. Developed countries offer more sophisticated infrastructures and greater experience in dealing with international capital flows, as well as greater integration into the world economic system. This study demonstrates the importance of these characteristics to investor perceptions of the value of firm earnings.

In addition, these results suggest that segment information reported under IFRS 14R in Taiwan has important information content, similar to that reported by Bodnar et al. (1997, 2003), using samples drawn from the United States, Australia, Canada, and the United Kingdom. It is important to know the informational quality resulting from these standards as they are implemented in disparate cultures and differentially developed economies. In this vein, we strongly suggest that further studies of segment disclosure be conducted in a wide variety of settings in order to better understand how national, cultural and developmental status-related factors impact investor reactions to earnings reports.

Finally, we note that this study has certain limitations, including using the data from just one country Taiwan. The relationships between foreign investments in lesser or more developed countries by Taiwanese firms, until relatively recently a lesser developed nation, may not hold in countries with a longer history of being considered fully developed. In addition, we did not include data from so-called 'tax heaven' countries, which enabled us to avoid the difficulty of classifying investees in these countries. This may also, however, constitute a limitation of our study. Overall, though, we believe that our results will be robust even when replicated using other countries as the source of the external development. 


\section{AUTHOR INFORMATION}

Chen-Lung Chin is a professor of accounting at National Chengchi University, Taipei, Taiwan. He is currently an Executive Editor of International Journal of Accounting Studies. His research interests include innovation disclosure, innovation valuation, analyst forecasts, and management forecasts. He has published papers in the Contemporary Accounting Research, Journal of Accounting, Auditing, and Finance, Journal of Forecasting, Review of Quantitative Finance and Accounting, and International Journal of Accounting Studies. E-mail: kim@nccu.edu.tw

Yu-Ju Chen is an associate professor of accounting at National Changhua University of Education, Taiwan. Her research interests include corporate governance, earnings management, international diversification and innovation strategy in business groups. She has published papers in Journal of Accounting, Auditing \& Finance and Industrial Marketing Management. E-mail: yujuchen@nccu.edu.tw

Gary Kleinman, CPA (Co.) is an associate professor of accounting at Montclair State University. He is co-editor of the research annual Applications of Management Science. It covers operations research and finance. He earned his doctorate from Rutgers University. He is the co-author of a very highly praised book entitled Understanding Auditor-Client Relationships: A Multi-faceted Analysis and a book on PCAOB auditing standards. Dr. Kleinman has published in many journals, including the Journal of International Accounting Research, Journal of Accounting, Auditing and Finance, Review of Quantitative Finance and Accounting, Research in Accounting Regulation, Group Decisions and Negotiations, and Human Communications Research. E-mail: kleinmang@montclair.edu

Picheng Lee is a professor of accounting at Pace University. He is also a certified management accountant (CMA) and an editorial board member of the International Journal of Accounting and Information Management. Dr. Lee's research interest is in financial accounting and auditing. His papers have been published in various journals including Auditing: A Journal of Practice and Theory, Journal of Accounting, Auditing, and Finance, Journal of Business and Economics Research, Journal of International Accounting Research, Journal of Forensic Accounting, and Review of Quantitative Finance and Accounting. E-mail: plee@ pace.edu. Corresponding author.

\section{REFERENCES}

1. Ball, R., S. Kothari and A. Robin 2000. The effect of international institutional factors on properties of accounting earnings. Journal of Accounting and Economics, 29, 1-52.

2. Beaver, W. H., Lambert, R. A., Ryan, S. G., 1987. The information content of security prices: A second look. Journal of Accounting and Economics 9, 139-157.

3. Belsley, D. A., Kuh, E., Welsch, R. E., 1980. Regression diagnostics, New York. NY: John Wiley \& Sons.

4. Bodnar, G. M., Weintrop, J., 1997. The valuation of foreign earnings: A growth opportunities perspective. Journal of Accounting and Economics 24, 69-97.

5. Bodnar, G. M., Hwang, L. S., Weintrop, J., 2003. The value relevance of foreign income: An Australian, Canadian, and British comparison. Journal of International Financial Management and Accounting 14 (3), 171-193.

6. Collins, D., Kothari, S., 1989. An analysis of the intertemporal and cross-sectional determinants of earnings response coefficients. Journal of Accounting and Economics 7, 143-181.

7. Dunning, J. H., 1998. Location and the multinational enterprise: A neglected factor? Journal of International Business Studies 29 (1), 1461-491.

8. Duru, A., Reeb, D. M., 2002. International diversification and analysts' forecast accuracy and bias. The Accounting Review 77 (2), 415-433.

9. Faccio, M, Lang, L. P. H., Young, L., 2001. Dividends and expropriation. American Economic Review 91, 54-78.

10. Gomez-Mejia, L., Palich, L., 1997. Cultural diversity and the performance of multinational firms. Journal of International Business Studies 28, 309-336.

11. Greene, W. H., 2000. Econometric analysis, 4th ed, New York, CA: Sage Publications.

12. Jiraporn, P., Kim, Y. S., Mathur, I., 2005. Does corporate diversification exacerbate or mitigate earnings management? An empirical analysis.' Working paper dated August 8, 2005. 
13. Kennedy, P, 1992. A guide to econometrics, Cambridge, MA: MIT Press.

14. Lev, B., Zarowin, P., 1999. The boundaries of financial reporting and how to extend them. Journal of Accounting Research 37, 353-385.

15. Lipe R., 1990. The relation between stock returns and accounting earnings given alternative information. The Accounting Review 65, 49-71.

16. Lipe, R. C., 1986. The information contained in the components of earnings. Journal of Accounting Research 24, 37-64.

17. Lu, J. W., Beamish, P. W, 2004. International diversification and firm performance: The S-curve hypothesis. Academy of Management Journal 47 (4), 598-609.

18. Lu, J. W., Beamish, P.W., 2001. The internationalization and performance of SMEs. Strategic Management Journal 22, 565-586.

19. Maines, A., McDaniel, L., 2000. Effects of comprehensive -income characteristics on nonprofessional investors' judgments: The role of financial-statement presentation format. The Accounting Review 75 (2), 179-207.

20. Morck, R., Yeung, B., 1991. Why investors value multinationality. Journal of Business 64 (2), 165-187.

21. Reason, T., 2005. The Narrowing GAAP: The convergence of foreign and domestic accounting rules could catch some U.S. companies by surprise, Found at http://www.cfo.com/article.cfm/5193385/c 5243641?f=magazine_coverstory on 4/27/2007.

22. Shleifer, A., Vishny, R., 1997. A Survey of Corporate Governance. Journal of Financial Economics 53, 737-783.

23. Sullivan, D., 1994. Measuring the degree of internationalization of a firm. Journal of International Business Studies 25 (2), 325-342.

24. Tallman, S., Li, J., 1996. Effects of international diversity and product diversity on the performance of multinational firms. Academy of Management Journal 39 (1), 179-196.

25. Tihanyi, L., Ellstrand, A. E., Daily, C. M., Daily, D. R., 2000.Composition of the top management team and firm international diversification. Journal of Management 26(6), 1157-1177.

26. Vafeas, N., 2000. Board structure and the informativeness of earnings. Journal of Accounting and Public Policy 19, 139-160.

27. White, H., 1980. A heteroskedasticity-consistent covariance matrix estimator and a direct test for heteroskedasticity. Econometrica 40, 617-636.

28. Young, C., Tsai, L., Hsu, H., 2008. The effect of controlling shareholders' excess board seats control on financial restatements: evidence from Taiwan. Review of Quantitative Finance and Accounting 30 (3), 297 314. 